ISSN 2326-3350

\title{
White Tea (Camellia Sinensis (L.)): Antioxidant Properties And Beneficial Health Effects
}

T. R. Dias, G. Tomás , N. F. Teixeira , M. G. Alves, P. F. Oliveira*, B. M. Silva*

Review Article

${ }^{1}$ CICS - UBI - Health Sciences Research Centre, University of Beira Interior, 6201-506 Covilhã, Portugal

\section{Abstract}

Tea is one of the most widely consumed beverages in the world, next to water. It can be categorized into three major types, depending on the level of fermentation, i.e., green and white (unfermented), oolong (partially fermented) and black (fermented) tea. Each type of tea has a distinct composition, dependent on how the leaves are processed, as well as maturation, geographical location and agricultural practices. White tea (W'T), the least processed tea, is one of the less studied and is ascribed to have the highest content of phenolic compounds. Tea polyphenols, especially catechin derivatives, are potent antioxidant agents, with positive effects on human health. Antioxidant components have aroused great interest because of their ability to scavenge free radicals, thereby inhibiting oxidative stress. During the past years, oxidative damage induced by reactive species has been linked to the development of several human diseases such as cardiovascular diseases, diabetes mellitus, neurodegenerative disorders and certain types of cancer. Therefore, tea antioxidants may be of great value in preventing the onset and/or the progression of oxidative stress mediated diseases, when endogenous defences are insufficient against reactive species. The possible beneficial health effects of WT are being investigated and have received considerable attention in recent years. In this review, we aim to explore the new findings concerning WT effects on health.

Keywords: White tea; Camellia sinensis; Polyphenols; Catechins; Antioxidants; Free radicals.

\section{*Corresponding Author:}

Branca Maria Silva,

Health Sciences Research Centre, Faculty of Health Sciences, University of Beira Interior,

Av. Infante D. Henrique, 6201-506 Covilhã, Portugal.

E-mail: bmcms@ubi.pt

Pedro Fontes Oliveira

Health Sciences Research Centre, Faculty of Health Sciences, University of Beira Interior, Av. Infante D. Henrique, 6201-506 Covilhã, Portugal

Email: poliveira@fcsaude.ubi.pt

Received: January 28, 2013

Accepted: February 20, 2013

Published: February 26, 2013

Citation: T. R. Dias, et al. (2013) White Tea (Camellia sinensis (L.)): Antioxidant Properties and Beneficial Health Effects. Int J Food Sci Nutr Diet. 2(2), 19-26. doi: http://dx.doi.org/10.19070/2326-3350-130005

Copyright: B. M. Silva ${ }^{\odot}$ 2013. This is an open-access article distributed under the terms of the Creative Commons Attribution License, which permits unrestricted use, distribution and reproduction in any medium, provided the original author and source are credited.

\section{Introduction}

Tea is one of the most widely consumed beverages in theworld, next to water [1,2] with a per capita consumption of $\sim 120 \mathrm{~mL} /$ day [3]. This popularity is probably related withits sensorial properties, relatively low retail price, stimulating effects and potential health benefits $[4,5]$. Despite tea is largely drunk for pleasure, its medicinal effects have been widely investigated, having a long, rich history with its first references nearly 5,000 years ago [6]. Tea is prepared as an infusion with the leaves of Camellia sinensis (L.), a plant cultivated in over 30 countries across the world that belongs to the Theaceae family [7]. There are two main varieties of tea plants: C. sinensis var. sinensis, a small-leaved, bushlike plant indigenous from China, which grows in several countries of Southeast Asia experiencing a cold climate, and C. sinensis var. assamica, a large-leaved tree discovered in the Assam region of India which grows in several countries with a semitropical climate [8]. There are different types of tea depending on botanical varieties, geographical origin and processing [8]. Concerning to the level of "fermentation", it can be categorized into three major types: not fermented (green and white tea), partially fermented (oolong tea) and completely fermented (black tea). Although this process is often assumed, incorrectly, to be fermentation, the most correct term should be oxidation (frequently followed by polymerization), which means exposure to $\operatorname{air}[9]$ and is a reaction catalyzed by the enzyme polyphenol oxidase [3]. To produce green tea (GT), the leaves are rolled and steamed to minimize oxidation and inactivate polyphenol oxidase prior to drying (Figure 1) [3]. In black tea production, after the leaves are rolled, which disrupts cellular compartmentation and brings phenolic compounds into contact with polyphenol oxidases, they undergo oxidation for 90-120 min [10]. Oolong tea is produced with a shorter "fermentation" period than black tea and has a taste and color somewhere between green and black teas [11]. White tea (WT) is prepared from very young tea leaves or buds covered with tiny, silvery hairs, which are harvested only once a year in the early spring [10]. The buds may be shielded from sunlight during growth to reduce the formation of chlorophyll, giving the young leaves a white appearance [12]. In WT production, plant materials are steamed and dried immediately after picking to prevent oxidation, giving it a light and delicate taste [10]. According to Almajano et al., it is one of the less studied teas but its flavor is more accepted in Europe than that of GT [13].

Although health benefits have been attributed to tea consumption since the beginning of its history, scientific investigations of this beverage and its constituents have been underway for less than three decades. Tea contains several bioactive compounds that are believed to have a wide range of physiological proper- 
Figure 1. Schematic representation of tea processing.

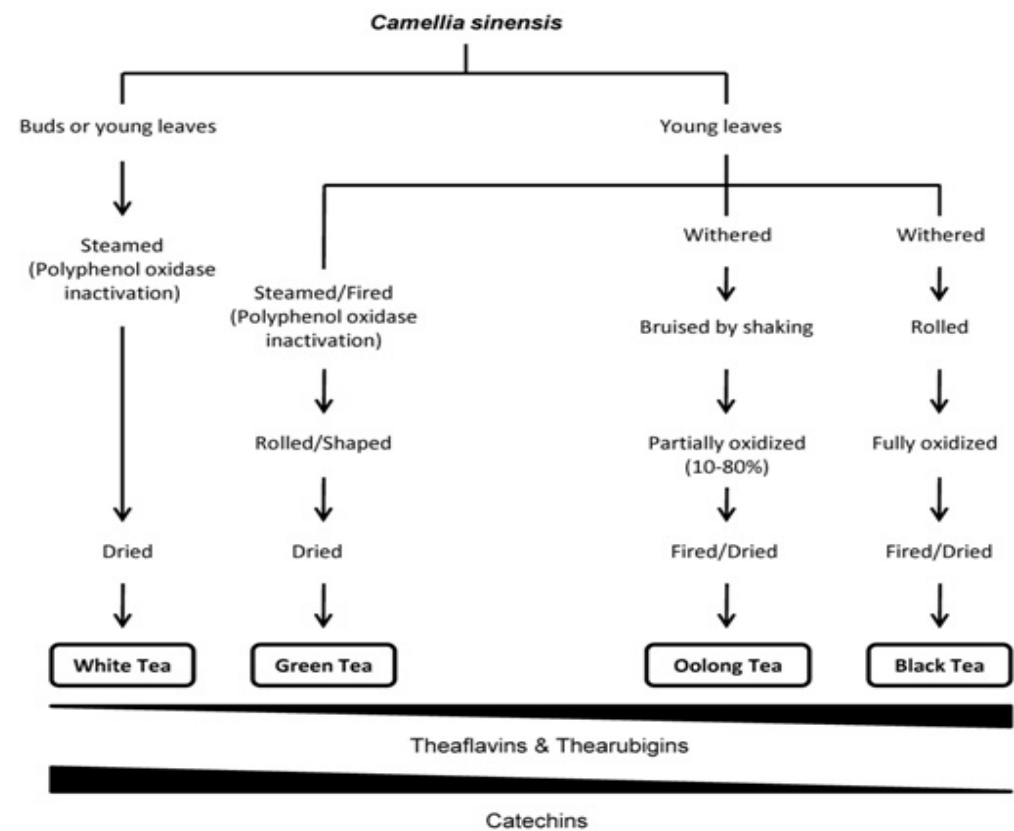

ties, including being stimulants [14] and antidepressants [15], anti-inflammatory [16-18], antioxidant [19-22], antiatherosclerotic [23], antihypertensive [24], anti-infectious diseases [25], antimutagenic [26,27], anticarcinogenic and anticancer promoting [28-30] antimicrobial [31,32], hypolipidemic [33,34], hypocholesterolemic [35], neuroprotective [36], and antidiabetic agents [37,38], as well as improving immune responses[39,40]] in several studies. Despite many of these physiological mechanisms are associated with the chemical properties of polyphenols and their healthy antioxidant effects, they are still controversial $[13,41]$. In spite of numerous data about the phenolic constituents, antioxidant activity and ameliorating effects of green and black tea on human health, little is known in this sense about WT, which is the rarest and the least processed tea[10]. The possible beneficial health effects of WT are being investigated and have received a great deal of attention in recent years. The purpose of this review is to bring together the most recent scientific information about the properties of WT and their physiological effects.

\section{White tea chemical composition}

The chemical composition of tea leaves has been thoroughly studied. The main constituents of tea include proteins, polysaccharides, polyphenols, minerals and trace elements, amino and organic acids, lignins, and methylxanthines (caffeine, theophylline, and theobromine) [42-43]. Apart from the energizing effect due to methylxanthines such as caffeine, phenolic compounds have received immense attention among tea phytochemicals, in particular flavonoids class [44]. Flavonoids are phenolic derivatives synthesized in substantial amounts $(0.5$ to $1.5 \%)$ that are widely distributed among plants [45] and have unique biological properties that may be responsible for many of the health benefits attributed to tea [46]. Over 4000 different flavonoids have been described, and they are categorized into flavonols, flavones, catechins, flavanones, anthocyanidins and isoflavonoids [47]. The major phenolic compounds present in tea leaves are catechins (also known as flavan-3-ols) and their derivatives, which constitute up to $30 \%$ of their dry weight. The main catechins present in WT are: (-)-epicatechin (EC), (-)-epigallocatechin (EGC), collectively known as flavanol monomers, (-)-epicatechin 3-gallate (ECG), and (-)-epi- gallocatechin 3-gallate (EGCG) (Figure 2), which are flavanol gallates $[8,41]$. EC has an ortho-dihydroxyl group in the B-ring at carbons $3^{\prime}$ and 4 ' and a hydroxyl group at carbon 3 on the C-ring (Figure 2). Differently of EC, EGC has a trihydroxyl group at carbons 3', 4', and 5' on the B-ring, while ECG has a gallate moiety esterified at carbon 3 of the C-ring and EGCG has both a trihydroxyl group at carbons 3', 4', and 5' on the B-ring and a gallate moiety esterified at carbon 3 on the C-ring (Figure 2) [48]. EGCG is the most abundant catechin in tea leaves, representing $50-80 \%$ of the total catechins, and is thought to contribute to the beneficial effects ascribed to tea $[49,50]$. The oxidation by polyphenol oxidase during processing leads to the formation of catechins and gallic acid complexes such as theaflavins, theaflavinic acids, thearubigins and proanthocyanidin polymers [51,52]. Thearubigins, which have higher molecular weights, are poorly chemically characterized. Theaflavins are characterized by the benzotropolone ring structure and bright red-orange color, and contribute to the unique taste of black tea [50]. A typical tea beverage, prepared in a proportion of $1 \mathrm{~g}$ of dried leaves to $100 \mathrm{ml}$ water in a 3-min brew, usually contains $250-350 \mathrm{mg}$ tea solids, comprised of $30-42 \%$ catechins and 3-6\% caffeine [53]. Tea also contains small amounts of flavonols (kaempferol, quercetin and myricitin) in the form of glycosides [52]. Other bioactive compounds found in tea are gallic, p-coumaric and caffeic acids [42]. Tea also contains many amino acids, but L-theanine ( $\gamma$-glutamylethylamide), specific to the tea plant, is the most abundant, accounting for $50 \%$ of the total amino acids [54]. It is a free amino acid and is thought to be a flavourous constituent of tea leaves. It constitutes between 1 and $2 \%$ of the dry weight of tea [55]. Chlorophylls, carotenoids, lipids, and volatile compounds are not major constituents in a tea brew but they play an important role in the development of the aroma [54].

Each type of tea has a distinct composition. The relative catechins content of tea is dependent on how the leaves are processed prior to drying, as well as geographical location and growing conditions [3]. The flavonoid concentration also depends upon the type of tea (e.g., blended, decaffeinated, instant) and preparation (e.g., amount used, brew time, temperature) [3]. Highest concentrations of flavonoids are found in brewed hot tea $(541-692 \mu \mathrm{g} / \mathrm{mL})$ [56] 
Figure 2. Chemical structures of the main white tea catechins. The figure illustrates two phenolic rings (A- and B-rings), the dihydropyran heterocycle (C-ring), with a hydroxyl group on carbon 3 and the gallate group. EC: (-)-epicatechin; EGC: (-)-epigallocatechin; ECG: (-)-epicatechin 3-gallate and EGCG: (-)-epigallocatechin 3-gallate.
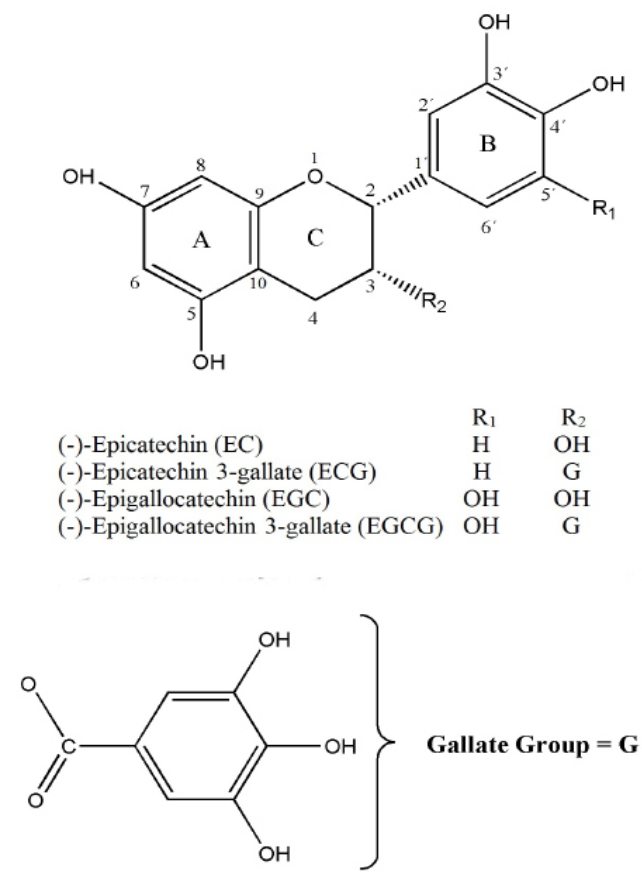

less in instant preparations $(90-100 \mu \mathrm{g} / \mathrm{mL}$ ) and lower amounts in iced and ready-to-drink tea [57]. According to the formation process it was reported that WT contains relatively high concentrations of catechins and low concentrations of theaflavins and thearubigins (Figure 1). Otherwise, the flavonol content in tea is less affected by processing, being present in comparable amounts in all teas [52]. Some reports showed that the concentrations of total polyphenols, total catechins, caffeine, gallic acid, theobromine, EGC, ECG and EGCG are significantly higher in the WT compared to GT $[58,59]$. Thus, the possible increased antioxidant activity of W'T could be related to higher concentrations of several of the major constituents [59]. However, there are studies reporting that GT is a richer source of polyphenols than WT [10] So, due to the contradictory studies reported in this field, it seems that the phenolic content is not an ideal criterion of differentiation between GT and WT.

\section{Antioxidant potential of white tea and associated health benefits}

In recent years, antioxidant components have aroused great interest because of their ability to scavenge free radicals, thereby inhibiting oxidation $[60,61]$. Most living organisms possess efficient enzymatic and non enzymatic defense systems against excess production of reactive oxygen and nitrogen species (RONS). However, different external factors (smoke, diet, alcohol, some drugs) and aging decrease the capability of such endogenous antioxidant defences, resulting in disturbances of the redox equilibrium that is established in healthy conditions [46,62]. Chronic exposure to RONS can damage DNA, membrane lipids, lipoproteins, and functional and structural proteins $[63,64]$. As during the past years, RONS-induced oxidative damage has been linked to the development of several human diseases such as cardiovascular diseases, diabetes mellitus, chronic inflammation, neurodegenerative disorders and certain types of cancer $[65,66]$, its reduction is seen as beneficial to public health. Therefore, antioxidants that scavenge RONS may be of great value in preventing the onset and/or the progression of oxidative diseases[62]. Tea polyphe- nols, especially catechin derivatives, are considered to be potent antioxidant agents, with a particularly important role in protecting against these deleterious diseases [13]. So, teas could be taken as a good complement to antioxidants intake in the human diet [67]. The antioxidant activity of phenolic compounds is mainly due to their redox properties, which allow them to act as reducing agents, singlet-oxygen quenchers and metallic-ion chelators[68]. Numerous studies have demonstrated that tea catechins and polyphenols are effective scavengers of physiologically relevant RONS in vitro, including superoxide $[69,70]$, peroxyl radicals, singlet oxygen[71], peroxynitrite [72,73] and hypochlorous acid [74]. Several structures appear to be important for these antioxidant activities of tea polyphenols (Figure 2), including the ortho-3',4'-dihydroxyl (catechol) group in the B-ring, that promotes the formation of a stable phenoxyl radical due to effective electron delocalization [75] or the 3',4',5'-trihydroxyl (gallate) group in the B-ring, a gallate group esterified at the 3 position of the C-ring, and hydroxyl groups at the 5 and 7 positions of the A-ring [76].

The knowledge of pharmacokinetics, absorption, distribution, metabolism, and excretion of tea components is essential to determine its potential bioactivities and overall significance in disease prevention [6]. Despite the proven antioxidant capacity of tea polyphenols, many clinical studies and animal models have shown that these compounds, especially the polymers, esters, and glycosides, are abundant, but are not always absorbed by oral administration. The functional effect of the compound depends not only on the amount ingested, but on its bioavailability [77]. Several clinical trials have demonstrated that a single dose of tea improves plasma antioxidant capacity of healthy adults within 30 to 60 minutes after ingestion[78-80]. In a recent study Koutelidakis et al. reported that supplementation of W'T extract for a five consecutive days not only increases the antioxidant capacity of plasma but also in different organs in mice, such as heart and lungs [81]. Despite catechins, especially EGCG, theaflavins and flavonol glycosides are also thought to be responsible for antioxidative properties of tea. The antioxidant effectiveness depends on the tea variety and the content of EGCG is very important [58]. Several epidemiological studies, experimentation with animals, 
Table 1. List of potential protective effects of white tea on cardiovascular diseases, cancer, diabetes mellitus, obesity, central nervous system and microorganism-induced diseases.

\begin{tabular}{|c|c|c|c|c|c|}
\hline \multicolumn{6}{|c|}{ Protective effects of White Tea } \\
\hline $\begin{array}{l}\text { Cardiovascular } \\
\text { diseases }\end{array}$ & Cancer & $\begin{array}{l}\text { Diabetes } \\
\text { mellitus }\end{array}$ & Obesity & $\begin{array}{c}\text { Central } \\
\text { nervous } \\
\text { system }\end{array}$ & $\begin{array}{l}\text { Microorganism- } \\
\text { induced diseases }\end{array}$ \\
\hline $\begin{array}{l}\text { Anti-thrombogen- } \\
\quad \text { ic activity }{ }^{190]}\end{array}$ & $\begin{array}{l}\text { Anti-mutagenic } \\
\text { activity }\end{array}$ & $\begin{array}{l}\text { Anti-diabetic } \\
\text { activity }\end{array}$ & $\begin{array}{l}\text { Stimulation of he- } \\
\text { patic lipid metabo- } \\
\text { lism }{ }^{[160]}\end{array}$ & $\begin{array}{l}\text { Anti-stress activ- } \\
\text { ity }{ }^{[148]}\end{array}$ & $\begin{array}{l}\text { Anti-microbial activ- } \\
\text { ity }{ }^{[31][32]}\end{array}$ \\
\hline $\begin{array}{l}\text { Hypotensive activ- } \\
\text { ity }{ }^{[95]}\end{array}$ & $\begin{array}{l}\text { Anti-carcinogen- } \\
\text { ic activity }{ }^{[28-30]}\end{array}$ & $\begin{array}{l}\text { Hypoglycemic } \\
\text { activity }{ }^{[109]}\end{array}$ & $\underset{[161]}{\text { Inhibition of lipase }}$ & $\begin{array}{l}\text { Stimulant activity } \\
{[14]}\end{array}$ & $\begin{array}{l}\text { Anti-fungal } \\
\text { activity }{ }^{[154]}\end{array}$ \\
\hline $\begin{array}{l}\text { Anti-inflammatory } \\
\text { activity }{ }^{[91]}\end{array}$ & $\begin{array}{l}\text { Anti-inflam- } \\
\text { matory activity } \\
{[123-126]}\end{array}$ & $\begin{array}{l}\text { Insulin resistance } \\
\text { reduction }\end{array}$ & $\begin{array}{l}\text { Thermogenic } \\
\text { activity }^{1161-163]}\end{array}$ & $\begin{array}{l}\text { Anti-depressant } \\
\text { activity }\end{array}$ & $\begin{array}{l}\text { Anti-viral } \\
\text { activity }{ }^{[25]}\end{array}$ \\
\hline $\begin{array}{l}\text { Antioxidant activ- } \\
\quad \text { ity }{ }^{[8,88]}\end{array}$ & $\begin{array}{l}\text { DNA damage } \\
\text { reduction }{ }^{[121]}\end{array}$ & $\begin{array}{l}\text { Antioxidant } \\
\text { activity }{ }^{[113,114]}\end{array}$ & $\begin{array}{l}\text { Modulation of ap- } \\
\text { petite }^{[164]}\end{array}$ & $\begin{array}{l}\text { Antioxidant activ- } \\
\text { ity }{ }^{[7]}\end{array}$ & \\
\hline & $\begin{array}{l}\text { Antioxidant } \\
\text { activity }^{[43]}\end{array}$ & \multicolumn{2}{|c|}{ Hypocholesterolemic activity ${ }^{[35]}$} & & \\
\hline & $\begin{array}{l}\text { Anti-angiogenic } \\
\text { activity }^{[121,128]}\end{array}$ & \multicolumn{2}{|c|}{$\begin{array}{l}\text { Lipolytic and antiadipogenic activities } \\
\text { [118] }\end{array}$} & & \\
\hline & & \multicolumn{2}{|c|}{ Hypolipidemic activity $^{[33,34]}$} & & \\
\hline
\end{tabular}

and in vitro studies lead to the conclusion that W'T has potentially protective effects for a wide variety of health conditions that are subsequently summarized (Table 1). However, the evidence is not always clear cut.

\section{Cardioprotective effects}

The onset of cardiovascular disease (CVD) depends on numerous factors that can be modulated by components in the diet [50]. Oxidative stress (OS) in cardiac and vascular myocytes has been linked with cardiovascular tissue injury [82]. RONS-induced OS is linked to the onset of various CVD such as atherosclerosis, ischemic heart disease, hypertension, cardiomyopathies, cardiac hypertrophy and congestive heart failure [83]. For instance, the oxidation of low density and very low density lipoproteins (LDL and VLDL) brings about the progressive obstruction of arteries or atherosclerosis, and can lead to coronary heart disease infarction [84]. Natural antioxidants, such as polyphenolic compounds of dietary origin, may inhibit lipid oxidation and attenuate the progress of atherosclerosis and thrombosis $[85,86]$. An epidemiologic study indicated that European populations with higher plasma concentrations of natural antioxidants, L-ascorbic acid and $\alpha$-tocopherol have a lower incidence of coronary heart disease [87]. The underlying mechanisms for the cardioprotective effect of tea include not only their antioxidant [88], antithrombogenic $[89,90]$. anti-inflammatory, vasculoprotective and lipid-lowering [91] properties but also to the improvement of coronary flow velocity reserve $[1,92]$. Several epidemiologic investigations indicated that flavonoid intake is inversely associated with the mortality of coronary heart disease $[90,93,94]$. In addition, flavonol glycosides have important activities against myocardial infarct and stroke but the mechanisms of action are not clearly known[58]. Tea catechins effectively reduce cholesterol absorption from the intestine, lowering the solubility of cholesterol and enhancing the faecal excretion of cholesterol and total lipids. In atheroscle- rosis, the inflammatory process is an important component and tea extract is known to induce an anti-inflammatory and capillary strengthening effect [84]. Other tea components, mainly quercetin [84] and L-theanine[95], reduce blood pressure in animals and in man and thus lower the risk for the development of cardiovascular diseases. Until now, there are still not evidences concerning the cardioprotective effects of WT. Although, since WT is richer in catechins and other polyphenols than other teas and those components are ascribed to have important cardioprotective roles, it is expected that WT will be beneficial against CVD. Further studies are needed to confirm WT potential against CVD.

\section{Antidiabetic potential}

Diabetes mellitus (DM) is an increasingly common, potentially devastating, expensive, treatable but incurable lifelong disease [96]. According to a widely accepted estimation, the number of diabetic patients will reach 366 million by the year 2030 [97]. It is a metabolic disorder of multiple aetiologies, characterized by chronic hyperglycemia and trouble some disruptions in carbohydrate, fat, and protein metabolisms emanating from deficiencies or disruptions in insulin secretion [98], defects in reactive oxygen species scavenging enzymes [99], and high oxidative stress impairing pancreatic beta cells $[100,101]$. Type $1 \mathrm{DM}$ results from an absolute deficiency of insulin due to an autoimmune destruction of the pancreatic beta cells while type $2 \mathrm{DM}$ is characterized by impaired insulin secretion and increased insulin resistance [102]. The levels of glycemia and insulinemia must be controlled in order to avoid later complications of DM, such as atherosclerosis, hypertension, hypertriglyceridemia, hypercholesterolemia, myocardial infarction, ischemic attacks, impotence, retinopathy and nephropathy [103]. The pharmacological treatment of DM includes oral hypoglycaemic and insulin. Although these drugs are effective in reducing glycaemia, they may cause undesirable side effects (such as weight gain, hypoglycemia, edema, gastroin- 
testinal disturbances and insulin resistance) that can discourage patient compliance [104]. In recent years, interest has increased in using natural products for pharmacological purposes, as a form of complementary or replacement therapy. Published reports show that numerous extracts obtained from plants are effective in reducing glycemia, causing fewer side effects and with lower cost than the usual antidiabetic agents [105-108]. There is some evidence that tea is a hypoglycemic agent [109]. In vitro rat studies suggest that EGCC and other catechins and theaflavins help prevent hyperglycemia by enhancing insulin activity and possibly by preventing damage to $\beta$-cells [37]. Although the exact mechanisms by which tea polyphenols ameliorate diabetes are not clear at the moment, all the studies suggest that polyphenols don't increase insulin secretion, but decrease insulin resistance and improve insulin sensitivity [110].

Various studies have reported that DM is associated with increased formation of RONS and decreased antioxidant potential [111]. Increased OS has been proposed to be one of the major causes of the hyperglycemia-induced trigger of diabetic complications [65]. Due to these events, the cellular balance between radical formation and protection against them is disturbed. In both insulin dependent and non-insulin-dependent diabetes there is increased OS[112]. It was previously shown that EGCG ameliorates cytokine-induced $\beta$-cell damage in vitro [113] and prevents the decrease of islet mass induced by treatment with multiple low doses of streptozotocin (STZ) in vivo [114]. However, in a latter study STZ was co-injected with EGCG, which possesses strong antioxidative activity [115], and it was unclear whether the protective effects observed in this study were due to direct inactivation of the co-injected STZ. Another study with EGCG reported that supplementation with it reduces serum glucose, total cholesterol and triglyceride and LDL-cholesterol in STZ-induced diabetic rats[116]. This effect however can be different from the effect of the tea extract, with all of its bioactive components. In contrast to studies indicating an antioxidative capacity of EGCG, investigations in the insulinoma cell line HIT-T15 showed that EGCG treatment was associated with increased production of RONS and reduced cell viability [117]. Thus, the antidiabetic effects of EGCG are not entirely clarified. The in vivo relevance of potentially antidiabetic WT catechins remains to be demonstrated. Recently, WT was reported to have strong lipolytic and antiadipogenic activity in vitro[118]. Hence, WTEA may demonstrate antidiabetic effect by reducing OS and hyperlipidemia followed by insulin resistance [110]. Since diabetes mellitus is increasing worldwide as is associated with several complications, there is a large interest in finding an effective therapy and W'T seems to be a good alternative. Furthermore, in-depth investigation is needed to fully understand the mechanisms of action of W'T against this disease.

\section{Anticarcinogenic and antimutagenic activities}

Cancer is generally considered as uncontrolled cell division that results in the aggregation of cells to form tumours. It is one of the major causes of death in the modern world and has shown to be a largely preventable disease, highly susceptible to modulation by dietary factors [119]. There are many factors which are involved in the pathogenesis of cancers, e.g. genetic mutations, smoking, heavy metal ingestion, and other pollution and indeed lack of proper diet [120]. OS induces a cellular redox imbalance, which has been found to be present in various cancer cells and may be related to oncogenic stimulation. Permanent modification of genetic material resulting from OS represents the first step in- volvedin mutagenesis, carcinogenesis, and ageing. DNA mutation is a critical step in carcinogenesis and elevated levels of oxidative DNA lesions have been noted in various tumours, strongly implicating such damage in the etiology of cancer [65]. Polyphenols present in tea may play an important role inthe prevention of cancer by decreasing DNA damage in the cell and reducing the activation of cancer that leads to malignancy [121]. Many studies have indicated that tea and its constituents, mainly EGCG, are antimutagenic and anti-inflammatory by intercepting carcinogenic agents and by reducing oxidant species before they can damage DNA [122,126]. Catechins also protect cell membranes against oxidation, keep RONS in confined zones and probably block cell membrane receptors required for cancer cell growth. The initiation of carcinogenesis can be overcome by the repression of some catalytic activities and of other specific enzymes involved in cancer initiation. This is complemented by the enhancement of detoxifying enzymes by EGCG[123,127].

In different cell lines and animal models, it has been shown that tea polyphenols inhibit angiogenesis, metastasis and cell proliferation, and induces cell cycle arrest and apoptosis through regulation of multiple signaling pathways [3,121]. For instance, Cao and Cao reported that EGCG inhibits angiogenesis [128]. Later, Sharangi showed that EGCG reduces angiogenesis in part by decreasing vascular endothelial growth factor (VEGF) production and receptor phosphorylation [121]. Importantly, the putative chemopreventive effect of tea also varies by the specific type of cancer [3]. So far, there are few studies concerning the anticarcinogenic potential of WT but recently it has been shown that WT has chemopreventive and antineoplastic effects in lung cancer cells [129] and can protect human skin from solar-stimulated ultraviolet light [130].

\section{Neuroprotective activity}

In the central nervous system (CNS), OS caused by increased production of RONS represents an important mechanism for neuronal dysfunction and cell loss in different neurodegenerative disorders [36]. The brain is particularly vulnerable to oxidative damage because of its high oxygen utilisation, its high content of oxidizable polyunsaturated fatty acids (PUFA), and the presence of redox-active metals (such as $\mathrm{Cu}, \mathrm{Fe}$ ) [65]. OS is one of the most important factors that contribute to aging processes and neurodegenerative disorders such as Alzheimer's disease, Parkinson's disease (PD) or Huntington's disease [131-134]. Although neuronal cells may respond to such stress using enzymatic and non-enzymatic detoxification mechanisms, there are certain populations of neurons that are particularly vulnerable to OS [132]. Food antioxidants may enhance the antioxidant capacity of the organism to prevent from neurodegenerative diseases associated with RONS and other oxidative damage inducing agents [7]. This neuroprotective effect has been ascribed to tea's high polyphenolic content, mainly of catechins and other flavanols[13,50,135-137]. Given that catechins exhibit higher antioxidant activity than theaflavins, it has been hypothesized that higher protection might be expected from teas that have undergone the minimal processing $[59,138]$, such as W'T and GT. W'T, which has received little attention for its health benefits, has similar or even higher antioxidant activity than certain GT[59,139-141].

Isolated constituents from tea have previously been demonstrated to exert protective effects in neuronal cells. For instance, EGCG was shown to have neuroprotective activity in a mice model of PD [142], and an epidemiologic study indicated that the risk of PD was reduced if tea consumption was $\geq 2$ cups/day [143]. In 
addition, L-theanine is ascribed to be a neuroprotective and cognitive enhancing agent $[144,145]$. It is thought to cross the bloodbrain barrier to exert its effects directly on the brain within 30 minutes [146]. Recently, L-theanine has been linked to the feelings of relaxation reported by those who drink tea. Experimental studies have also shown that L-theanine appears to negate some of the effects of caffeine[147]. It is believed to lower cortisol levels, thus reducing psychological and physiological stress[148]. In this sense, results suggest that protection may be due to a synergistic effect among various compounds of tea. Recently, using a model of striatal immortalized cell lines, Almajano et al. have evaluated the neuroprotective effect of W'T extracts against $\mathrm{H}_{2} \mathrm{O}_{2}$-induced toxicity [36]. They have demonstrated that WT is able to completely protect striatal cells from OS and suggested that WT consumption may have beneficial effects on neuronal cells contributing to reduce OS associated with age-related brain disorders.

\section{Antimicrobial properties}

Tea also exhibits some antimicrobial properties, which are attributed mainly to its polyphenols. The degree of this activity depends on the bacterial species and the polyphenol structure [149][150] Gram negative bacteria seem to be more resistant to polyphenols than Gram positive bacteria, due to differences in the exterior membrane [151]. The antimicrobial activity of nonfermented tea is higher than that of semi-fermented or fermented tea. Moreover, the highest antimicrobial activity occurs in samples with the highest total polyphenol concentration and antioxidant activity [152]. So, WT is expected to have higher antimicrobial activity than other teas. The main components responsible for the antimicrobial activity are EGCG and EGC, since these are also the ones with more antioxidant activity [153]. EGCG at 10-100 $\mu \mathrm{M}$ has showed to reduce Escherichia coli growth by approximately $50 \%[152]$.

The use of natural antioxidants as preservatives in food has great potential because consumers request additive-free, fresher and more natural-tasting food. However, it is necessary to maintain microbiological safety and minimize the number of food-borne microorganisms[152]. WT is considered to be one of the best sources of extracts that can act as microbiological inhibitors. The use of WT in combination with other antimicrobial additives or methods for stabilizing food products represents an alternative way of maintaining a high flavour quality without the use of conventional food preservatives.

Despite the beneficial effect against food microorganisms, the anti-Candida activity of tea and its catechin derivatives has also been reported. The antifungal effects of tea catechins upon Candida albicans has been described, alone or combined with classic antifungals, such as amphotericin B and fluconazole [154]. Pyrogallolcatechins, namely EGCG, EGC, gallocatechin and gallocatechin 3-gallate, present stronger antifungal activity against Candida albicans than catechol catechins, such as EC, ECG, catechin and catechin 3-gallate. The synergic activity between EGCG and those antimycotics has also been shown in this study [154]. In fact, EGCG acts as an antifolate agent, disturbing Candida albicans folic acid metabolism and consequently inhibiting ergosterol synthesis [155]. The antimycotic activity towards Candida albicans has been described to be higher in non-fermented (W'T and GT) than in semi-fermented (oolong tea) or fermented (black tea) teas [13]. In addition, it has been reported that EGCG and EGC inhibit retrovirus human immunodeficiency virus (HIV) propagation by inhibiting reverse transcriptase, an enzyme which allows the establishment of the virus in host cells [156]. Therefore, WT can also be a very interesting alternative to fight microorganismsinduced diseases. Nevertheless, this field needs further investigation.

\section{Anti-obesity potential}

Although there are many proposed genetic and environmental factors that predispose individuals to weight gain, the fundamental cause of obesity is an imbalance between dietary intake and energy expenditure [157]. It is known to be a strong risk factor for lifestyle-related diseases [121]. Obesity has increased at an alarming rate in recent years and is now a worldwide health problem [158]. While conventional weight management programs show only limited success, particularly in the long-term, there is growing interest in alternative strategies for weight management. One natural ingredient in focus is tea. Some reports indicate that intake of tea catechins, together with regular exercise helps to reduce diet-induced obesity. This effect might be attributed to the activation of whole-body energy metabolism [121]. Bose et al. reported that treatment with $7.0 \mathrm{mmol} / \mathrm{g}$ dietary EGCG for 15 weeks reduced body weight gain $(33-41 \%)$ in high-fat-fed male C57bl/6J mice compared with high-fat-fed controls [159]. The mechanisms of action of tea in obesity are: stimulation of hepatic lipid metabolism [160]; inhibition of lipases [161]; stimulation of thermogenesis [161,163]; modulation of appetite [164]; and synergism with caffeine [165][166]. Simple tea drinking may have easier acceptance by the patients than prescription drugs, exercise and bariatric surgery. The main attractions of tea as an anti-obesity agent are that it is a more natural and safer alternative, there is no need for professional supervision and it is readily accessible and affordable [167]. Although laboratorial studies using animal models have largely demonstrated obesity preventive effects of GT, the effectiveness of WT has been less studied. Söhle et al. recently reported that WT extract effectively inhibits adipogenesis and stimulates lipolysis-activity [118]. Therefore, WT is an ideal natural source to modulate the adipocyte life cycle at different stages and to induce anti-obesity effects. However, the role of tea polyphenols and specifically of WT in the prevention of obesity has not been fully elucidated.

\section{Future Perspectives}

Even if up to date findings demonstrate the protective effect of W'T against the OS, characteristic in the pathology of several human diseases, more in-depth research is needed to clearly define the health benefits and clinical effects of this rare type of tea. Therefore, we expect to have contributed to the future expansion of research on WT and to promote W'T consumption since it has been shown to be a promising agent for prevention and treatment of several human diseases.

\section{Acknowledgements}

This work was supported by the "Fundação para a Ciência e a Tecnologia" - FCT (PTDC/QUI-BIQ/121446/2010 and PEstC/SAU/UI0709/2011) co-funded by Fundo Europeu de Desenvolvimento Regional - FEDER via Programa Operacional Factores de Competitividade - COMPETE/QREN. M.G. Alves (SFRH/BPD/80451/2011) was funded by FCT. P.F. Oliveira was funded by FCT through FSE and POPH funds (Programa Ciência 2008).

\section{References}


[1]. Cheng TO (2004) Will green tea be even better than black tea to increase coronary flow velocity reserve? American Journal of Cardiology 94(9): 12231223.

[2]. Vinson JA (2000) Black and green tea and heart disease: a review. BioFactors 13(1-4): 127-132.

[3]. Mckay DL, Blumberg JB (2002) The role of tea in human health: an update. Journal of the American College of Nutrition 21(1): 1-13.

[4]. Baptista JaB, Tavares JFP, Carvalho RCB (1998) Comparison of catechins and aromas among different green teas using HPLC/SPME-GC. Food Research International 31(10): 729-736.

[5]. Baptista JaB, Da P Tavares JF, Carvalho RCB (1999) Comparative study and partial characterization of Azorean green tea polyphenols. Journal of Food Composition and Analysis 12(4): 273-287.

[6]. Wheeler DS, Wheeler WJ (2004) The medicinal chemistry of tea. Drug Development Research 61(2): 45-65.

[7]. López V, Calvo MI (2011) White tea (Camellia sinensis Kuntze) exerts neuroprotection against hydrogen peroxide-induced toxicity in PC12 cells. Plant Foods for Human Nutrition (Formerly Qualitas Plantarum) 66(1): 22-26.

[8]. De Mejia EG, Ramirez-Mares MV, Puangpraphant S (2009) Bioactive components of tea: cancer, inflammation and behavior. Brain, Behavior, and Immunity 23(6): 721-731.

[9]. Bartlett A (2004) Fine teas flower in the bay area. New York Times: 8 .

[10]. Rusak G, Komes D, Likić S, Horžić D, Kovač M (2008) Phenolic content and antioxidative capacity of green and white tea extracts depending on extraction conditions and the solvent used. Food Chemistry 110(4): 852-858.

[11]. Del Rio D, Stewart AJ, Mullen W, Burns J, Michael E, et al. (2004) HPLCMSn analysis of phenolic compounds and purine alkaloids in green and black tea. Journal of Agricultural and Food Chemistry 52(10): 2807-2815.

[12]. Alcazar A, Ballesteros O, Jurado J, Pablos F, Martin M, et al. (2007) Differentiation of green, white, black, Oolong, and Pu-erh teas according to their free amino acids content. Journal of Agricultural and Food Chemistry 55(15): 5960-5965.

[13]. Almajano MP, Carbo R, Jiménez J, Gordon MH (2008) Antioxidant and antimicrobial activities of tea infusions. Food Chemistry 108(1): 55-63.

[14]. Liu K, Liang X, Kuang W (2011) Tea consumption maybe an effective active treatment for adult attention deficit hyperactivity disorder (ADHD). Medical Hypotheses 76(4): 461-463.

[15]. Zhu WL, Shi HS, Wei YM, Wang SJ, Sun CY, et al. (2011) Green tea polyphenols produce antidepressant-like effects in adult mice. Pharmacological Research.

[16]. Sano M, Suzuki M, Miyase T, Yoshino K, Maeda-Yamamoto M (1999) Novel antiallergic catechin derivatives isolated from oolong tea. Journal of Agricultural and Food Chemistry 47(5): 1906-1910.

[17]. Cavet ME, Harrington KL, Vollmer TR, Ward KW, Zhang JZ (2011) Antiinflammatory and anti-oxidative effects of the green tea polyphenol epigallocatechin gallate in human corneal epithelial cells. Molecular Vision 17: 533.

[18]. Melillo De Magalhães P, Dupont I, Hendrickx A, Joly A, Raas T, et al. (2012) Anti-inflammatory effect and modulation of cytochrome P450 activities by Artemisia annua tea infusions in human intestinal Caco-2 cells. Food Chemistry.

[19]. Yen GC, Chen HY, Peng HH (1997) Antioxidant and pro-oxidant effects of various tea extracts. Journal of Agricultural and Food Chemistry 45(1): 30-34.

[20]. Lin YL, Juan IM, Chen YL, Liang YC, Lin JK (1996) Composition of polyphenols in fresh tea leaves and associations of their oxygen-radical-absorbing capacity with antiproliferative actions in fibroblast cells. Journal of Agricultural and Food Chemistry 44(6): 1387-1394.

[21]. Costa RM, Magalhães AS, Pereira JA, Andrade PB, Valentão P, et al. (2009) Evaluation of free radical-scavenging and antihemolytic activities of quince (Cydonia oblonga) leaf: A comparative study with green tea (Camellia sinensis). Food and Chemical Toxicology 47(4): 860-865.

[22]. Carloni P, Tiano L, Padella L, Bacchetti T, Customu C, et al. (2012) Antioxidant activity of white, green and black tea obtained from the same tea cultivar. Food Research International.

[23]. Curin Y, Andriantsitohaina R (2005) Polyphenols as potential therapeutical agents against cardiovascular diseases. Pharmacological Reports 57: 97.

[24]. Hodgson JM, Burke V, Puddey IB (2005) Acute effects of tea on fasting and postprandial vascular function and blood pressure in humans. Journal of Hypertension 23(1): 47-54.

[25]. Weber JM, Ruzindana-Umunyana A, Imbeault L, Sircar S (2003) Inhibition of adenovirus infection and adenain by green tea catechins. Antiviral Research 58(2): 167-173.

[26]. Jain A, Shimoi K, Nakamura Y, Kada T, Hara Y, et al. (1989) Crude tea extracts decrease the mutagenic activity of $\mathrm{N}$-methyl- $\mathrm{N}$-nitro- $\mathrm{N}$-nitrosoguanidine in vitro and in intragastric tract of rats. Mutation Research/Fundamental and Molecular Mechanisms of Mutagenesis 210(1): 1-8.

[27]. Bhattacharya U, Mukhopadhyay S, Giri AK (2011) Comparative antimutagenic and anticancer activity of three fractions of black tea polyphenols thearubigins. Nutrition and Cancer 63(7): 1122-1132.
[28]. Katiyar SK, Agarwal R, Zaim MT, Mukhtar H (1993) Protection against $\mathrm{N}$-nitrosodiethylamine and benzo [a] pyrene-induced forestomach and lung tumorigenesis in $\mathrm{A} / \mathrm{J}$ mice by green tea.Carcinogenesis $14(5)$ : 849-855.

[29]. Carvalho M, Jerónimo C, Valentấo P, Andrade PB, Silva BM (2010) Green tea: A promising anticancer agent for renal cell carcinoma.Food Chemistry 122(1): 49-54.

[30]. Genkinger JM, Li R, Spiegelman D, Anderson KE, Albanes D, et al. (2012) Coffee, tea, and sugar-sweetened carbonated soft drink intake and pancreatic cancer risk: a pooled analysis of 14 cohort studies. Cancer Epidemiology Biomarkers \& Prevention 21(2): 305-318.

[31]. Chou CC, Lin LL, Chung KT (1999) Antimicrobial activity of tea as affected by the degree of fermentation and manufacturing season. International Journal of Food Microbiology 48(2): 125-130.

[32]. Von Staszewski M, Pilosof AMR, Jagus RJ (2011) Antioxidant and antimicrobial performance of different Argentinean green tea varieties as affected by whey proteins. Food Chemistry 125(1): 186-192.

[33]. Yoshino K, Tomita I, Sano M, Oguni I, Hara Y, et al. (1994) Effects of longterm dietary supplement of tea polyphenols on lipid peroxide levels in rats. Age 17(3): 79-85.

[34]. Huang HC, Lin JK (2012) Pu-erh tea, green tea, and black tea suppresses hyperlipidemia, hyperleptinemia and fatty acid synthase through activating AMPK in rats fed a high-fructose diet. Food \& Function 3(2): 170-177.

[35]. Maron DJ, Lu GP, Cai NS, Wu ZG, Li YH, et al. (2003) Cholesterol-lowering effect of a theaflavin-enriched green tea extract: a randomized controlled trial. Archives of Internal Medicine 163(12): 1448.

[36]. Almajano M, Vila I, Ginés S (2011) Neuroprotective effects of white tea against oxidative stress-induced toxicity in striatal cells. Neurotoxicity Research 20(4): 372-378.

[37]. Anderson RA, Polansky MM (2002) Tea enhances insulin activity. Journal of Agricultural and Food Chemistry 50(24): 7182-7186.

[38]. Abolfathi AA, Mohajeri D, Rezaie A, Nazeri M (2012) Protective Effects of Green Tea Extract against Hepatic Tissue Injury in Streptozotocin-Induced Diabetic Rats. Evidence-Based Complementary and Alternative Medicine 2012.

[39]. Bhattacharyya A, Mandal D, Lahiry L, Sa G, Das T (2004) Black tea protects immunocytes from tumor-induced apoptosis by changing $\mathrm{Bcl}-2 / \mathrm{Bax}$ ratio. Cancer Letters 209(2): 147-154.

[40]. Sheikhzadeh N, Nofouzi K, Delazar A, Oushani AK (2011) Immunomodulatory effects of decaffeinated green tea (Camellia sinensis) on the immune system of rainbow trout (Oncorhynchus mykiss). Fish \& Shellfish Immunology.

[41]. Galleano M, Oteiza PI, Fraga CG (2009) Cocoa, chocolate and cardiovascular disease. Journal of Cardiovascular Pharmacology 54(6): 483.

[42]. Seeram NP, Henning SM, Niu Y, Lee R, Scheuller HS, et al. (2006) Catechin and caffeine content of green tea dietary supplements and correlation with antioxidant capacity. Journal of Agricultural and Food Chemistry 54(5): 1599-1603.

[43]. Moderno P, Carvalho M, Silva B (2009) Recent patents on Camellia sinensis: source of health promoting compounds. Recent Patents on Food, Nutrition and Agriculture 1(3): 182 .

[44]. Cabrera C, Giménez R, López MC (2003) Determination of tea components with antioxidant activity. Journal of Agricultural and Food Chemistry 51(15): 4427-4435.

[45]. Vinson JA, Dabbagh YA, Serry MM, Jang J (1995) Plant flavonoids, especially tea flavonols, are powerful antioxidants using an in vitro oxidation model for heart disease. Journal of Agricultural and Food Chemistry 43(11): 2800-2802.

[46]. Rietveld A, Wiseman S (2003) Antioxidant effects of tea: evidence from human clinical trials. The Journal of nutrition 133(10): 3285S-3292S.

[47]. Firenzuoli F, Gori L, Crupi A, Neri D (2004) Flavonoids: risks or therapeutic opportunities. Recenti Progressi in Medicina 95: 345-351.

[48]. Graham HN (1992) Green tea composition, consumption, and polyphenol chemistry. Preventive Medicine 21(3): 334-350.

[49]. Ortsäter H, Grankvist N, Wolfram S, Kuehn N, Sjöholm Å (2012) Diet supplementation with green tea extract epigallocatechin gallate prevents progression to glucose intolerance in $\mathrm{db} / \mathrm{db}$ mice. Nutrition and Metabolism 9(1): 11 .

[50]. Khan N, Mukhtar H (2007) Tea polyphenols for health promotion. Life Sciences 81(7): 519-533.

[51]. Song J, Xu H, Liu F, Feng L (2012) Tea and cognitive health in late life: Current evidence and future directions. The Journal of Nutrition, Health \& Aging 16(1): 31-34.

[52]. Balentine DA, Wiseman SA, Bouwens LCM (1997) The chemistry of tea flavonoids. Critical Reviews in Food Science and Nutrition 37(8): 693-704.

[53]. Mukhtar H, Ahmad N (1999) Cancer chemoprevention: future holds in multiple agents. Toxicology and Applied Pharmacology 158(3): 207-210.

[54]. Dufresne C, Farnworth E (2000) Tea, Kombucha, and health: a review. Food Research International 33(6): 409-421.

[55]. Cartwright R, Roberts E, Wood D (1954) Theanine, an amino-acid n-ethyl amide present in tea. Journal of the Science of Food and Agriculture 5(12): 
597-599.

[56]. Hakim I, Weisgerber U, Harris R, Balentine D, Van-Mierlo C, et al. (2000) Preparation, composition and consumption patterns of tea-based beverages in Arizona. Nutrition Research 20(12): 1715-1724

[57]. Arts ICW, Van De Putte B, Hollman PCH (2000) Catechin contents of foods commonly consumed in The Netherlands. 1. Fruits, vegetables, staple foods, and processed foods. Journal of Agricultural and Food Chemistry 48(5): 1746-1751.

[58]. Hilal Y, Engelhardt U (2007) Characterisation of white tea-Comparison to green and black tea. Journal für Verbraucherschutz und Lebensmittelsicherheit 2(4): 414-421.

[59]. Santana-Rios G, Orner GA, Amantana A, Provost C, Wu SY, et al. (2001) Potent antimutagenic activity of white tea in comparison with green tea in the Salmonella assay. Mutation Research-Genetic Toxicology and Environmental Mutagenesis 495(1): 61-74.

[60]. Wongkham S, Laupattarakasaem P, Pienthaweechai K, Areejitranusorn P, Wongkham C, et al. (2001) Antimicrobial activity of Streblus asper leaf extract. Phytotherapy Research 15(2): 119-121.

[61]. Jin D, Hakamata H, Takahashi K, Kotani A, Kusu F (2004) Determination of quercetin in human plasma after ingestion of commercial canned green tea by semi-micro HPLC with electrochemical detection. Biomedical Chromatography 18(9): 662-666.

[62]. Willett WC (1994) Diet and health: what should we eat. Science 264(5158): $532-537$.

[63]. Halliwell B (1997) Antioxidants and human disease: a general introduction. Nutrition Reviews 55(1): S44-S49.

[64]. Sohal RS, Weindruch R (1996) Oxidative stress, caloric restriction, and aging. Science (New York, NY) 273(5271): 59

[65]. Valko M, Leibfritz D, Moncol J, Cronin MTD, Mazur M, et al. (2007) Free radicals and antioxidants in normal physiological functions and human disease. International Journal of Biochemistry and Cell Biology 39(1): 44-84.

[66]. Valko M, Rhodes C, Moncol J, Izakovic M, Mazur M (2006) Free radicals, metals and antioxidants in oxidative stress-induced cancer. Chemico-Biological Interactions 160(1): 1-40.

[67]. Alarcón E, Campos A, Edwards A, Lissi E, López-Alarcón C (2008) Antioxidant capacity of herbal infusions and tea extracts: A comparison of ORACfluorescein and ORAC-pyrogallol red methodologies. Food Chemistry 107(3): 1114-1119.

[68]. Atoui AK, Mansouri A, Boskou G, Kefalas P (2005) Tea and herbal infusions: their antioxidant activity and phenolic profile. Food Chemistry 89(1): 27-36.

[69]. Nanjo F, Honda M, Okushio K, Matsumoto N, Ishigaki F, et al. (1993) Effects of dietary tea catechins on alpha-tocopherol levels, lipid peroxidation, and erythrocyte deformability in rats fed on high palm oil and perilla oil diets. Biological \& Pharmaceutical Bulletin 16(11): 1156

[70]. Nakagawa T, Yokozawa T (2002) Direct scavenging of nitric oxide and superoxide by green tea. Food and Chemical Toxicology 40(12): 1745-1750.

[71]. Guo Q, Zhao B, Shen S, Hou J, Hu J, et al. (1999) ESR study on the structure-antioxidant activity relationship of tea catechins and their epimers. Biochimica et Biophysica Acta (BBA)-General Subjects 1427(1): 13-23.

[72]. Haenen GRMM, Paquay JBG, Korthouwer REM, Bast A (1997) Peroxynitrite scavenging by flavonoids. Biochemical and Biophysical Research Communications 236(3): 591-593.

[73]. Paquay JBG, Haenen GRMM, Stender G, Wiseman SA, Tijburg LBM, et al. (2000) Protection against nitric oxide toxicity by tea. Journal of Agricultural and Food Chemistry 48(11): 5768-5772.

[74]. Scott BC, Butler J, Halliwell B, Aruoma OI (1993) Evaluation of the antioxidant actions of ferulic acid and catechins. Free Radical Research 19(4): 241-253.

[75]. Wiseman SA, Balentine DA, Frei B (1997) Antioxidants in tea. Critical Reviews in Food Science and Nutrition 37(8): 705-718

[76]. Rice-Evans CA, Miller NJ, Paganga G (1996) Structure-antioxidant activity relationships of flavonoids and phenolic acids. Free Radical Biology and Medicine 20(7): 933-956.

[77]. Holst B, Williamson G (2008) Nutrients and phytochemicals: from bioavailability to bioefficacy beyond antioxidants. Current Opinion in Biotechnology 19(2): 73-82.

[78]. Leenen R, Roodenburg A, Tijburg L, Wiseman S (2000) A single dose of tea with or without milk increases plasma antioxidant activity in humans. European Journal of Clinical Nutrition 54(1): 87.

[79]. Benzie I, Szeto Y, Strain J, Tomlinson B (1999) Consumption of green tea causes rapid increase in plasma antioxidant power in humans. Nutrition and Cancer 34(1): 83-87.

[80]. Sung H, Nah J, Chun S, Park H, Yang S, et al. (2000) In vivo antioxidant effect of green tea. European Journal of Clinical Nutrition 54(7): 527.

[81]. Koutelidakis AE, Argiri K, Serafini M, Proestos C, Komaitis M, et al. (2009) Green tea, white tea, and Pelargonium purpureum increase the antioxidant capacity of plasma and some organs in mice. Nutrition 25(4): 453-458.

[82]. Dhalla NS, Temsah RM, Netticadan T (2000) Role of oxidative stress in cardiovascular diseases. Journal of Hypertension 18(6): 655-673.
[83]. Kukreja RC, Hess ML (1992) The oxygen free radical system: from equations through membrane-protein interactions to cardiovascular injury and protection. Cardiovascular Research 26(7): 641-655.

[84]. Tijburg L, Mattern T, Folts J, Weisgerber U, Katan M (1997) Tea flavonoids and cardiovascular diseases: a review. Critical Reviews in Food Science and Nutrition 37(8): 771-785.

[85]. Kinsella J, Frankel E, German B, Kanner J (1993) Possible mechanisms for the protective role of antioxidants in wine and plant foods: physiological mechanisms by which flavonoids, phenolics, and other phytochemicals in wine and plant foods prevent or ameliorate some common chronic diseases are discussed. Food Technology 47(4): 85-89.

[86]. Frankel E, German J, Kinsella J, Parks E, Kanner J (1993) Inhibition of oxidation of human low-density lipoprotein by phenolic substances in red wine. The Lancet 341(8843): 454-457.

[87]. Gey K, Brubacher G, Stahelin H (1987) Plasma levels of antioxidant vitamins in relation to ischemic heart disease and cancer. American Journal of Clinical Nutrition 45 .

[88]. Cheng TO (2000) Tea is good for the heart. Archives of Internal Medicine 160(15): 2397.

[89]. Hertog MGL (1996) Epidemiological evidence on potential health properties of flavonoids. Proceedings of the Nutrition Society 55(1): 385-398.

[90]. Hertog MGL, Feskens EJM, Kromhout D, Hollman P, Katan M (1993) Dietary antioxidant flavonoids and risk of coronary heart disease: the Zutphen Elderly Study. The Lancet 342(8878): 1007-1011.

[91]. Stangl V, Lorenz M, Stangl K (2006) The role of tea and tea flavonoids in cardiovascular health. Molecular Nutrition \& Food Research 50(2): 218228.

[92]. Hirata K, Shimada K, Watanabe H, Otsuka R, Tokai K, et al. (2004) Black tea increases coronary flow velocity reserve in healthy male subjects. The American journal of cardiology 93(11): 1384-1388.

[93]. Hertog MGL, Feskens EJM, Kromhout D (1997) Antioxidant flavonols and coronary heart disease risk. The Lancet 349(9053): 699.

[94]. Rimm EB, Katan MB, Ascherio A, Stampfer MJ, Willett WC (1996) Relation between intake of flavonoids and risk for coronary heart disease in male health professionals. Annals of Internal Medicine 125(5): 384.

[95]. Yokogoshi H, Kato Y, Sagesaka YM, Takihara-Matsuura T, Kakuda T, et al. (1995) Reduction effect of theanine on blood pressure and brain 5-hydroxyindoles in spontaneously hypertensive rats. Bioscience, Biotechnology, and Biochemistry 59(4): 615

[96]. Al-Attar AM, Zari TA (2010) Influences of crude extract of tea leaves, Camellia sinensis, on streptozotocin diabetic male albino mice. Saudi Journal of Biological Sciences 17(4): 295-301

[97]. Wild S, Roglic G, Green A, Sicree R, King H (2004) Global prevalence of diabetes estimates for the year 2000 and projections for 2030. Diabetes Care 27(5): 1047-1053.

[98]. Ugochukwu N, Babady N, Cobourne M, Gasset S (2003) The effect ofGongronema latifolium extracts on serum lipid profile and oxidative stress in hepatocytes of diabetic rats. Journal of biosciences 28(1): 1-5.

[99]. Kesavulu M, Giri R, Rao BK, Apparao C (2008) Lipid peroxidation and antioxidant enzyme levels in type 2 diabetics with microvascular complications.

[100]. Baliga V, Sapsford R (2009) Review article: Diabetes mellitus and eart failure-an overview of epidemiology and management. Diabetes and Vascular Disease Research 6(3): 164-171.

[101]. Hamden K, Jaouadi B, Carreau S, Aouidet A, Elfeki A (2011) Therapeutic effects of soy isoflavones on $\bigotimes$-amylase activity, insulin deficiency, liver-kidney function and metabolic disorders in diabetic rats. Natural Product Research 25(3): 244-255.

[102]. Consultation W (1999) Definition, diagnosis and classification of diabetes mellitus and its complications. Geneva, Switzerland: World Health Organization: 31-3.

[103]. Stadler K, Jenei V, Von Bölcsházy G, Somogyi A, Jakus J (2003) Increased nitric oxide levels as an early sign of premature aging in diabetes.Free Radical Biology and Medicine 35(10): 1240-1251.

[104]. Vasconcelos C, Maranhăo H, Batista T, Carneiro E, Ferreira F, et al. (2011) Hypoglycaemic activity and molecular mechanisms of Caesalpinia ferrea Martius bark extract on streptozotocin-induced diabetes in Wistar rats. Journal of Ethnopharmacology 137(3): 1533-1541.

[105]. Gupta RK, Kesari AN, Murthy P, Chandra R, Tandon V, et al. (2005) Hypoglycemic and antidiabetic effect of ethanolic extract of leaves of Annona squamosa L. in experimental animals. Journal of Ethnopharmacology 99(1): 75-81.

[106]. Sohn E, Kim J, Kim CS, Kim YS, Jang DS, et al. (2010) Extract of the aerial parts of Aster koraiensis reduced development of diabetic nephropathy via anti-apoptosis of podocytes in streptozotocin-induced diabetic rats. Biochemical and Biophysical Research Communications 391(1): 733-738.

[107]. Pushparaj P, Tan C, Tan B (2000) Effects of Averrhoa bilimbi leaf extract on blood glucose and lipids in streptozotocin-diabetic rats. Journal of Ethnopharmacology 72(1): 69-76.

[108]. Lee MS, Sohn CB (2009) Anti-diabetic activities of ethanol extracts from persimmon leaves. Journal of the Korean Society for Applied Biological 
Chemistry 52(1): 96-97.

[109]. Mackenzie T, Leary L, Brooks WB (2007) The effect of an extract of green and black tea on glucose control in adults with type 2 diabetes mellitus: double-blind randomized study. Metabolism 56(10): 1340-1344.

[110]. Islam M (2011) Effects of the aqueous extract of white tea (Camellia sinensis) in a streptozotocin-induced diabetes model of rats. Phytomedicine 19(1): $25-31$.

[111]. Rahimi R, Nikfar S, Larijani B, Abdollahi M (2005) A review on the role of antioxidants in the management of diabetes and its complications. Biomedicine and Pharmacotherapy 59(7): 365-373.

[112]. Naziroğlu M, Butterworth PJ (2005) Protective effects of moderate exercise with dietary vitamin $\mathrm{C}$ and $\mathrm{E}$ on blood antioxidative defense mechanism in rats with streptozotocin-induced diabetes. Canadian Journal of Applied Physiology 30(2): 172-185.

[113]. Han MK (2003) Epigallocatechin gallate, a constituent of green tea, suppresses cytokine-induced pancreatic beta-cell damage. Experimental and Molecular Medicine 35(2): 136-139.

[114]. Song EK, Hur H, Han MK (2003) Epigallocatechin gallate prevents autoimmune diabetes induced by multiple low doses of streptozotocin in mice. Archives of Pharmacal Research 26(7): 559-563.

[115]. Abe I, Kashiwagi K, Noguchi H (2000) Antioxidative galloyl esters as enzyme inhibitors of p-hydroxybenzoate hydroxylase. FEBS Letters 483(2): 131-134.

[116]. Roghani M, Baluchnejadmojarad T (2010) Hypoglycemic and hypolipidemic effect and antioxidant activity of chronic epigallocatechin-gallate in streptozotocin-diabetic rats. Pathophysiology 17(1): 55-9.

[117]. Suh KS, Chon S, Oh S, Kim SW, Kim JW, et al. (2010) Prooxidative effects of green tea polyphenol (-)-epigallocatethin-3-gallate on the HITT15 pancreatic beta cell line. Cell Biology and Toxicology 26(3): 189-199.

[118]. Söhle J, Knott A, Holtzmann U, Siegner R, Grönniger E, et al. (2009) White Tea extract induces lipolytic activity and inhibits adipogenesis in human subcutaneous (pre)-adipocytes. Nutr Metab (Lond) 6: 20.

[119]. Fresco P, Borges F, Diniz C, Marques M (2006) New insights on the anticancer properties of dietary polyphenols. Medicinal Research Reviews 26(6): 747-766

[120]. Noonan DM, Benelli R, Albini A (2007) Angiogenesis and cancer prevention: a vision. Cancer Prevention: 219-224.

[121]. Sharangi A (2009) Medicinal and therapeutic potentialities of tea (Camellia sinensis L.)-A review. Food Research International 42(5): 529-535.

[122]. Halder J, Bhaduri AN (1998) Protective role of black tea against oxidative damage of human red blood cells. Biochemical and Biophysical Research Communications 244(3): 903-907.

[123]. Katiyar SK, Mukhtar H (1997) Inhibition of phorbol ester tumor promoter 12-O-tetradecanoylphorbol-13-acetate-caused inflammatory responses in SENCAR mouse skin by black tea polyphenols. Carcinogenesis 18(10): 1911-1916.

[124]. Mitscher LA, Jung M, Shankel D, Dou JH, Steele L, et al. (1997) Chemoprotection: a review of the potential therapeutic antioxidant properties of green tea (Camellia sinensis) and certain of its constituents. ChemInform 28(41).

[125]. Yang CS, Wang ZY (1993) Tea and cancer. Journal of the National Cancer Institute 85(13): 1038-1049.

[126]. Yen GC, Chen HY (1995) Antioxidant activity of various tea extracts in relation to their antimutagenicity. Journal of Agricultural and Food Chemistry 43(1): 27-32.

[127]. Bushman JL (1998) Green tea and cancer in humans: a review of the literature. Nutrition and Cancer 31(3): 151-159.

[128]. Cao Y, Cao R (1999) Angiogenesis inhibited by drinking tea. Nature 398(6726): 381-381.

[129]. Mao JT, Nie WX, Tsu IH, Jin YS, Rao JY, et al. (2010) White Tea Extract Induces Apoptosis in Non-Small Cell Lung Cancer Cells: the Role of Peroxisome Proliferator-Activated Receptor- $\nabla$ and 15-Lipoxygenases. Cancer Prevention Research 3(9): 1132-1140.

[130]. Camouse MM, Domingo DS, Swain FR, Conrad EP, Matsui MS, et al. (2009) Topical application of green and white tea extracts provides protection from solar-simulated ultraviolet light in human skin. Experimental Dermatology 18(6): 522-526.

[131]. Sian J, Dexter DT, Lees AJ, Daniel S, Agid Y, et al. (2004) Alterations in glutathione levels in Parkinson's disease and other neurodegenerative disorders affecting basal ganglia. Annals of Neurology 36(3): 348-355.

[132]. Wang X, Michaelis EK (2010) Selective neuronal vulnerability to oxidative stress in the brain. Frontiers in aging neuroscience 2.

[133]. Multhaup G, Ruppert T, Schlicksupp A, Hesse L, Beher D, et al. (1997) Reactive oxygen species and Alzheimer's disease. Biochemical Pharmacology 54(5): 533.

[134]. Halliwell B (2006) Oxidative stress and neurodegeneration: where are we now? Journal of Neurochemistry 97(6): 1634-1658.

[135]. Stewart AJ, Mullen W, Crozier A (2004) On-line high-performance liquid chromatography analysis of the antioxidant activity of phenolic compounds in green and black tea. Molecular Nutrition \& Food Research 49(1):
$52-60$.

[136]. Mandel S, Amit T, Reznichenko L, Weinreb O, Youdim MBH (2006) Green tea catechins as brain-permeable, natural iron chelators-antioxidants for the treatment of neurodegenerative disorders. Molecular Nutrition \& Food Research 50(2): 229-234.

[137]. Tipoe GL, Leung TM, Hung MW, Fung ML (2007) Green tea polyphenols as an anti-oxidant and anti-inflammatory agent for cardiovascular protection. Cardiovascular \& Haematological Disorders-Drug Targets 7(2): $135-144$.

[138]. Hernaez JF, Xu M, Dashwood RH (1998) Antimutagenic activity of tea towards 2-hydroxyamino-3-methylimidazo [4, 5-f] quinoline: effect of tea concentration and brew time on electrophile scavenging. Mutation Research 402(1-2): 299.

[139]. Thring TSA, Hili P, Naughton DP (2009) Anti-collagenase, antielastase and anti-oxidant activities of extracts from 21 plants. BMC Complementary and Alternative Medicine 9(1): 27.

[140]. Unachukwu UJ, Ahmed S, Kavalier A, Lyles JT, Kennelly EJ (2010) White and green teas (Camellia sinensis var. sinensis): variation in phenolic, methylxanthine, and antioxidant profiles. Journal of Food Science 75(6): C541-C548.

[141]. Müller N, Ellinger S, Alteheld B, Ulrich-Merzenich G, Berthold HK, et al. (2010) Bolus ingestion of white and green tea increases the concentration of several flavan-3-ols in plasma, but does not affect markers of oxidative stress in healthy non-smokers. Molecular Nutrition \& Food Research 54(11): 1636-1645.

[142]. Levites Y, Weinreb O, Maor G, Youdim MBH, Mandel S (2001) Green tea polyphenol (-)-epigallocatechin-3-gallate prevents $\mathrm{N}$-methyl4-phenyl-1, 2, 3, 6-tetrahydropyridine-induced dopaminergic neurodegeneration. Journal of Neurochemistry 78(5): 1073-1082.

[143]. Checkoway H, Powers K, Smith-Weller T, Franklin GM, Longstreth W, et al. (2002) Parkinson's disease risks associated with cigarette smoking, alcohol consumption, and caffeine intake. American Journal of Epidemiology 155(8): 732-738.

[144]. Dimpfel W, Kler A, Kriesl E, Lehnfeld R (2007) Theogallin and Ltheanine as active ingredients in decaffeinated green tea extract: II. Characterization in the freely moving rat by means of quantitative field potential analysis. Journal of Pharmacy and Pharmacology 59(10): 1397-1403.

[145]. Nathan PJ, Lu K, Gray M, Oliver C (2006) The Neuropharmacology of L-Theanine (N-Ethyl-L-Glutamine). Journal of Herbal Pharmacotherapy 6(2): 21-30

[146]. Unno T, Suzuki Y, Kakuda T, Hayakawa T, Tsuge H (1999) Metabo-

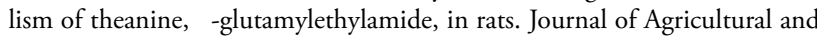
Food Chemistry 47(4): 1593-1596.

[147]. Fackelmann K (1997) The Cortisol Connection. Science News: 350351.

[148]. Kimura K, Ozeki M, Juneja LR, Ohira H (2007) L-Theanine reduces psychological and physiological stress responses. Biological Psychology 74(1): 39-45.

[149]. Campos FM, Couto JA, Hogg TA (2003) Influence of phenolic acids on growth and inactivation of Oenococcus oeni and Lactobacillus hilgardii. Journal of Applied Microbiology 94(2): 167-74.

[150]. Taguri T, Tanaka T, Kouno I (2004) Antimicrobial activity of 10 different plant polyphenols against bacteria causing food-borne disease. Biological and Pharmaceutical Bulletin 27(12): 1965-1969.

[151]. Negi P, Jayaprakasha G, Jena B (2003) Antioxidant and antimutagenic activities of pomegranate peel extracts. Food Chemistry 80(3): 393-397.

[152]. Nazer A, Kobilinsky A, Tholozan JL, Dubois-Brissonnet F (2005) Combinations of food antimicrobials at low levels to inhibit the growth of Salmonella sv. Typhimurium: a synergistic effect? Food Microbiology 22(5): 391-398.

[153]. Gramza A, Korczak J (2005) Tea constituents (Camellia sinensis L.) as antioxidants in lipid systems. Trends in Food Science \& Technology 16(8): 351-358.

[154]. Hirasawa M, Takada K (2004) Multiple effects of green tea catechin on the antifungal activity of antimycotics against Candida albicans. Journal of Antimicrobial Chemotherapy 53(2): 225-9.

[155]. Navarro-Martinez MD, Garcia-Canovas F, Rodriguez-Lopez JN (2006) Tea polyphenol epigallocatechin-3-gallate inhibits ergosterol synthesis by disturbing folic acid metabolism in Candida albicans. Journal of Antimicrobial Chemotherapy 57(6): 1083-92.

[156]. Yamamoto T, Juneja LR, Kim M (1997) Chemistry and applications of green tea. CRC

[157]. Rains TM, Agarwal S, Maki KC (2011) Antiobesity effects of green tea catechins: a mechanistic review. The Journal of nutritional biochemistry 22(1): $1-7$.

[158]. Cheng TO (2004) Obesity crisis comprised of danger and opportunity. Journal of the American Dietetic Association 104(10): 1546.

[159]. Bose M, Lambert JD, Ju J, Reuhl KR, Shapses SA, et al. (2008) The major green tea polyphenol,(-)-epigallocatechin-3-gallate, inhibits obesity, metabolic syndrome, and fatty liver disease in high-fat-fed mice. The Journa 
of nutrition 138(9): 1677-1683.

[160]. Murase T, Nagasawa A, Suzuki J, Hase T, Tokimitsu I (2002) Beneficial effects of tea catechins on diet-induced obesity: stimulation of lipid catabolism in the liver. International Journal of Obesity 26(11): 1459-1464.

[161]. Chantre P, Lairon D (2002) Recent findings of green tea extract AR25 (Exolise) and its activity for the treatment of obesity. Phytomedicine 9(1): 3-8.

[162]. Dulloo AG, Duret C, Rohrer D, Girardier L, Mensi N, et al. (1999) Efficacy of a green tea extract rich in catechin polyphenols and caffeine in increasing 24-h energy expenditure and fat oxidation in humans. The American journal of clinical nutrition 70(6): 1040-1045.

[163]. Dulloo A, Seydoux J, Girardier L, Chantre P, Vandermander J (2000) Green tea and thermogenesis: interactions between catechin-polyphenols, caffeine and sympathetic activity. International Journal of Obesity 24(2): 252-258.

[164]. Liao S (2001) The medicinal action of androgens and green tea epigallocatechin gallate. Hong Kong Medical Journal 7(4): 369-374.

[165]. Zheng G, Sayama K, Okubo T, Juneja LRaJ, Oguni I (2004) Antiobesity effects of three major components of green tea, catechins, caffeine and theanine, in mice. In Vivo 18(1): 55-62.

[166]. Kovacs EMR, Lejeune M, Nijs I, Westerterp-Plantenga MS (2004) Effects of green tea on weight maintenance after body-weight loss. British Journal of Nutrition 91(3): 431-438.

[167]. Heber D (2003) Herbal preparations for obesity: are they useful? Primary Care 30(2): 441. 